\author{
Pawel Żukowski \\ Wyższa Szkoła Biznesu \\ National - Louis University w Nowym Sączu
}

\title{
Wymiar profesjonalny i osobowościowy współczesnego menedżera
}

Współcześnie zarządzanie organizacjami w warunkach światowej globalizacji gospodarki oraz coraz szerszych i głębszych procesów integracji stawia menedżerom różnych poziomów hierarchicznych wielowymiarowe wymagania w sferze kwalifikacji, głównie w zakresie wiedzy, umiejętności i doświadczenia - w tym kompetencji menedżerskich, cech osobowości, zachowań etyczno-moralnych (systemu celów i wartości). W każdej organizacji pożądana jest też znajomość problemów psychospołecznych, bowiem predyspozycje psychosocjologiczne, inteligencja ${ }^{1}$, aktywność zawodowa przesądzają o różnicach w wynikach uczenia się i sprawności kierowania w porównywalnych warunkach działania. Wymagania te są jednak zmienne w czasie i przestrzeni, często nawet pozostają w sprzeczności, co dodatkowo utrudnia i komplikuje zarządzanie.

Współczesny menedżer może efektywnie pełnić swoje podstawowe role i funkcje kierownicze oraz sprawnie realizować zadania, jeśli ma nie tylko odpowiednią wiedzę ogólną i specjalistyczną, doświadczenie, pożądany zespół cech osobowości, zdolności ${ }^{2}$, inteligencję, ale też podstawowe, konkretne umiejętności menedżerskie, utrwalone jako nawyki. Powinien także odznaczać się szczególnymi wrodzonymi predyspozycjami osobowymi i interpersonalnymi, wyobraźnią, odwagą, zdolnościami przywódczymi, by mógł sprawnie zarządzać organizacją i umieć współpracować z wieloma instytucjami, spełniając oczekiwania swoich klientów i partnerów, a także uważnie analizować postępowanie konkurencji na rynku. Sprawne oddziaływanie menedżera na organizacyjne zachowania podwładnych wymaga też od niego wrodzonych zdolności kierowniczych (Wachowiak 2001, Żukowski 2006).

Z wymienionych wyżej względów menedżer powinien umieć rozpoznawać, analizować i rozwiązywać złożone problemy organizacyjno-zarządcze oraz podejmować właściwe decyzje związane ze sprawnym funkcjonowaniem i rozwojem współczesnych organizacji. Zarządzanie wymaga od niego przede wszystkim asertywności, kreatywności i przedsiębiorczości, by umiał przeciwstawiać się pokusom sukcesu i łatwego zysku, był odpowiedzialny, opanowany, przezorny i odnosił się z szacunkiem do człowieka, rozwijał i doskonalił w sobie właśnie te pozytywne cechy, a jednocześnie był odważny, wytrwały i inspirował innych pracowników do działania, by był tolerancyjny wobec całej różnorodności form kultury. Powinien być kosmopolitą.

\footnotetext{
${ }^{1}$ Inteligencję należy rozumieć jako zdolności do przystosowywania się do nowych okoliczności i wymagań, analitycznego i racjonalnego myślenia, spostrzegania istniejących zależności i wyciągania stosownych wniosków, sprawnego rozwiązywania zadań intelektualnych i skutecznego działania, a także wariantowego formułowania i wyboru właściwej, adekwatnej do celu i zadań, strategii i działań operacyjnych oraz właściwego zachowania się w sytuacjach nagłych (stresowych).

${ }^{2}$ Zdolności mogą być ogólne, będące dyspozycjami poznawczymi uwarunkowanymi biologicznie, lub specjalne, które - dzięki aktywności jednostki ludzkiej - kształtują się w procesie oddziaływania (interakcji) ośrodkowego układu nerwowego ze środowiskiem.
} 
Od sprawności pracy personelu menedżerskiego zależą w głównej mierze sukcesy rynkowe organizacji. Ze względu na ciągle zmieniające się różne elementy otoczenia, wymagające coraz częściej szybkich, a nawet natychmiastowych reakcji, praca kierownicza jest stresogenna, szczególnie trudna i odpowiedzialna. Wymaga ona od menedżera, jak zaznaczono wyżej, określonych predyspozycji psychotechnicznych, szczególnych cech osobowości, wiedzy i umiejętności oraz doświadczenia, a także uwzględniania w pracy kierowniczej uznawanego systemu wartości. O sukcesie menedżera, a tym samym organizacji, decydują również jakość wykształcenia, gotowość do ciągłego podnoszenia wiedzy ogólnej i poszerzania umiejętności kierowniczych, co stanowi poważny i cenny zasób wiedzy menedżera i współczesnej organizacji.

Osiągnięcie przez współczesnego menedżera prawdziwego sukcesu (nie tylko finansowego) wymaga także od niego postępowania zgodnego z uznanymi zasadami etyczno-moralnymi (Rachwał T., Rachwał M. 2006). Jak wskazuje doświadczenie historyczne, prawdziwy sukces w biznesie osiągają ci menedżerowie, którzy mają wiedzę, umiejętności, doświadczenie, pożądaną osobowość, inteligencję, wyobraźnię, odwagę i zdolności przywódcze, ale zarazem są uczciwi i przyzwoici, a w swojej pracy zarządczej kierują się uznanymi zasadami etycznomoralnymi. Wymagania stawiane współczesnym menedżerom mają więc charakter wielowymiarowy i są coraz wyższe (Szczupaczyński 1998, Penc 2001, Kuc 2004, Żukowski 2005).

Menedżer w organizacji spełnia (co najmniej) następujące role: interpersonalną (nawiązywanie i utrzymanie kontaktów z innymi ludźmi), informacyjną (zbieranie, przetwarzanie i przekazywanie informacji) i decyzyjną (dysponowanie zasobami organizacji), a także negocjacyjną (umiejętności prowadzenia negocjacji). Funkcje menedżera wynikają z podstawowych funkcji zarządzania organizacją (planowania, organizowania, motywowania, marketingu i kontrolowania) (Bartkowiak, Januszek 1999, Stoner, Freeman, Gilbert 2001, Kubik 2005, Wołowiec 2009).

Prezentowana wielowymiarowa sylwetka menedżera powinna uwzględniać współczesną tendencję rozwoju cywilizacyjnego, która charakteryzuje się przechodzeniem od industrialnej i postindustrialnej faz rozwoju do fazy społeczeństwa informacyjnego. Podczas gdy podstawą materialną fazy rozwoju industrialnego był rozwój przemysłu, a fazy postindustrialnej - rozwój usług, to podstawą ekonomiczną rozwoju społeczeństwa informacyjnego są zasoby intelektualne wynikające z zasobów wiedzy jednostek ludzkich i zespołów pracowniczych. Współczesny menedżer powinien więc także posiadać (nabyć) umiejętności zarządzania wiedzą w organizacji.

W tej pracy przedstawimy jedynie podstawowe składniki sylwetki współczesnego menedżera, eksponując jej zasadnicze wymiary: profesjonalny i osobowościowy.

\section{Wymiar profesjonalny menedżera}

\section{Role, funkcje i zadania menedżera}

Menedżerem jest osoba na stanowisku kierowniczym, która ma odpowiednią wiedzę i umiejętności, w tym kierownicze, pożądaną osobowość oraz doświadczenie w kierowaniu zespołami pracowniczymi i zarządzaniu organizacjami w warunkach niepewności i nieokreśloności oraz stałej zmienności otoczenia. Każda organizacja, zwłaszcza obecnie, w warunkach globalizacji gospodarki, potrzebuje skutecznych i efektywnych w działaniu menedżerów, gdyż głównie oni stają się kreatorami jej sukcesu. Role, funkcje i zadania menedżerów w warunkach globalizacji i integracji są bardzo szerokie, a ich realizacja wymaga nowoczesnej wiedzy i zespołu umiejętności, wielkiego wysiłku i poświęcenia.

Praca kierownika-menedżera polega głównie na ustalaniu celów i określaniu zadań, po uprzednim zbadaniu rynku, wypracowaniu i podjęciu - stosownie do okoliczności i zasobów 
- właściwych decyzji, organizowaniu ich realizacji, motywowaniu podwładnych do wydajnej i efektywnej pracy oraz kontrolowaniu ich działań. Menedżer odpowiada nie tylko za realizację celów i zadań, zapewnienie wysokiej wydajności pracy, racjonalnego wykorzystywania zasobów (czynników produkcji), ale także za tworzenie przyjaznej atmosfery, wzajemnego zaufania, otwartości w pracy i warunków pobudzających inicjatywę i przedsiębiorczość oraz poczucie odpowiedzialności wśród podwładnych. Zadaniem menedżera jest ponadto zapewnienie odpowiednich warunków do celowej i harmonijnej współpracy w zespole. Jego rola polega również na właściwym przydzielaniu zadań i środków, kontroli działań i ocenie pracowników. Pracownik powinien mieć pewność, że jego praca zostanie obiektywnie oceniona, a jej efekty spotkają się z należytym uznaniem. Zadaniem menedżera jest też inspirowanie, popieranie i motywowanie działań podległych pracowników, a także eliminowanie przeszkód w realizacji zadań.

W gospodarce rynkowej globalizującego się świata wymagania wobec menedżera polegają na tym, by - rozumiejąc strategię organizacji, w tym zwłaszcza strategiczne cele marketingowe - wiedział on zarazem, w jaki sposób swoim działaniem może przyczynić się do sukcesu organizacji. Z powodu szerokiego zakresu obowiązków i kompetencji menedżerów powstają określone ich specjalizacje, z których każda wymaga ciągłego zdobywania wiedzy ogólnej i specjalistycznej, stałego doskonalenia umiejętności i specjalizowania się w pewnym zakresie.

Od każdego menedżera, bez względu na poziom zarządzania, zajmowane stanowisko i pełnione funkcje, wymaga się skuteczności i efektywności w pracy kierowniczej. W pracy tej bowiem wiedza i umiejętności menedżerskie, osobowość, doświadczenie, inteligencja, wyobraźnia, to elementy kluczowe, ale ich właściwe zespolenie ocenia się po skuteczności działania (po rezultatach). Skuteczność menedżera w każdej instytucji ma wielką wartość, w głównej mierze przyczynia się bowiem do jej sprawnego funkcjonowania, sukcesu i rozwoju. Dwa ważne pojęcia - skuteczność i efektywność - związane z pracą menedżera są jednocześnie ogólnymi miarami jego powodzenia w zarządzaniu (Drucker 1994). Zarządzanie jest skuteczne, gdy organizacja osiąga założone cele, efektywne zaś wówczas, gdy - przestrzegając zasady racjonalnego gospodarowania - oszczędnie i starannie gospodaruje się posiadanymi zasobami i osiąga możliwie najlepsze wyniki finansowe. Zadaniem menedżera jest zachowanie równowagi pomiędzy skutecznością a efektywnością. Dla skutecznego zarządzania menedżer powinien umiejętnie wypełniać podstawowe funkcje kierownicze, przestrzegając jednocześnie zasad zarządzania i stosując jego nowoczesne metody i techniki, a także prezentując właściwy styl kierowania.

Ch. Coates opracował listę zadań menedżera; ważniejsze to:

- określenie, w jakim stopniu instytucja jest zorientowana na klientów, czy pracownicy wszystkich działów mają dostateczną wiedzę na temat potrzeb i oczekiwań klientów;

- ocena, które z przyjętych w instytucji sposobów pomiaru zadowolenia klientów są właściwe, czy pomiary te są wyczerpujące, czy przepływ informacji od klientów jest efektywny;

- zaangażowanie wszystkich działów w debatę na temat wyników uzyskiwanych przez instytucję w zakresie zaspokajania potrzeb klientów;

- określenie podstawowych kryteriów, które brane są pod uwagę przy podejmowaniu przez klientów decyzje o zakupach;

- badanie kierunków i tempa ewolucji potrzeb i oczekiwań klientów w różnych segmentach;

- określenie, czy przyjęta przez instytucję segmentacja klientów i rynku jest dostatecznie szczegółowa, czy organizacja dysponuje dokładnymi informacjami na temat zachowań nabywców;

- badanie, czy instytucja dysponuje wzmacniającą się ofertą i przewagą w stosunku do konkurencji, a także którym kryteriom zakupu instytucja powinna poświęcić najwięcej uwagi, aby uzyskać natychmiastową lub widoczną w dłuższych okresach poprawę (Coates 1998). 
Według P. F. Druckera, zadaniem menedżera jest:

- zarządzanie przez wyznaczanie celów;

- podejmowanie większego ryzyka i umiejętność skalkulowania z większym wyprzedzeniem każdego ryzyka i wybrania najkorzystniejszego wariantu;

- zdolność do stworzenia zintegrowanego zespołu, w którym każdy potrafi ocenić swoją wydajność i wyniki w odniesieniu do wspólnego celu;

- umiejętność szybkiego i jasnego przekazywania informacji;

- motywowanie pracowników do efektywnej pracy;

- postrzeganie ekonomicznych, politycznych i społecznych zjawisk w skali krajowej i światowej oraz uwzględnianie ich w swoich działaniach; a także:

- kierowanie własnym rozwojem i działaniami, zdobywanie nowych umiejętności i doskonalenie cech osobowych oraz własnej pracy menedżerskiej;

- kierowanie pracownikami przez zrozumienie ich potrzeb i oczekiwań oraz właściwe wykorzystanie ich wiedzy, umiejętności i uzdolnień dla dobra instytucji;

- sterowanie rozwojem instytucji przez znajomość jej misji i celów, mocnych i słabych stron potencjału organizacji oraz szans i zagrożeń, jakie niesie otoczenie;

- rozwiązywanie problemów, podejmowanie stosownych do sytuacji decyzji oraz wprowadzanie ich w życie (Drucker 1994).

Menedżer powinien dokładać wszelkich starań, by podlegli mu pracownicy mieli jasność celów i realizacji przydzielonych zadań, a ewentualnie uprzednio uczestniczyli w ich ustalaniu. Zadaniem menedżera jest stworzenie takich warunków, by zachodziła zgodność lub wysoka korelacja celów poszczególnych pracowników z celami instytucji. Ma to miejsce w organizacji wtedy, gdy w miarę wzrostu wydajności pracy, poprawy produktywności i rentowności, następuje poprawa zaspokajania potrzeb pracowników. Menedżerowie starający się podnieść atrakcyjność produktów (wytwarzanych dóbr i świadczonych usług) powinni w pierwszym rzędzie zaakceptować taktykę orientacji na klientów, zwrócić uwagę na podstawowe ich potrzeby, życzenia i oczekiwania. Orientacja na klientów musi być podstawą sformułowania strategii instytucji, jej struktury organizacyjnej, procesów i procedur postępowania, jak również kształtowania i wykorzystywania wiedzy - zasobu wiadomości i umiejętności oraz doświadczenia przedsiębiorczych menedżerów, a także opracowania systemu motywacji pracowników (Stoner, Freeman, Gilbert 2001, Koźmiński, Piotrowski 2006, Żukowski 2006).

Ważnym zadaniem menedżera jest obiektywna ocena pracy podwładnych oraz sprawiedliwe wyróżnianie i nagradzanie. Nagrody powinny być tak rozdzielane, aby pełniły rolę instrumentów motywujących do efektywnej pracy. W każdej instytucji powinien być wypracowany określony, jawny system nagradzania pracowników. Zadaniem i jednocześnie umiejętnością menedżera jest biegłość w posługiwaniu się krytyką jako narzędziem doskonalenia postępowania pracowników, tak aby nie zniechęcać ich do pracy, lecz pobudzać ich do poprawiania popełnionych błędów i eliminowania ich w przyszłości.

Skutecznych menedżerów charakteryzuje pewna szczególna cecha: mają oni jasność i zrozumienie celu i zadań tej części organizacji, za której funkcjonowanie ponoszą odpowiedzialność. Koncentrują swoją uwagę na określonych wielkościach - miernikach, np. na wydajności pracy i jej jakości, nowoczesności produktów, kosztach wytwarzania lub świadczenia usług, zysku, rentowności. Zespołem pracowniczym kierują tak, by każdy pracownik mógł w pełni wykorzystać swoją wiedzę i zdolności oraz istniejące możliwości. Dzięki temu uzyskują wysoką efektywność pracy zespołu, ukierunkowaną na osiąganie najważniejszych celów całej organizacji (Krzyżanowski 1999, Stoner, Wankel 2001, Banaszak 2006, Kubik 2008, Wołowiec 2009). 
Menedżerowie najwyższego poziomu zarządzania, formułując strategię rozwoju organizacji, modelując koncepcję jej przyszłości, oprócz odpowiednich kwalifikacji muszą mieć wyobraźnię, odwagę i inicjatywę, być przedsiębiorczy, ambitni, operatywni, żądni sukcesu. Od poziomu ich profesjonalizmu - wiedzy, umiejętności i doświadczenia, a także zdolności i cech wyżej wymienionych - zależy w głównej mierze sprawność funkcjonowania i biznesowa kondycja organizacji (Szczupaczyński 1998, Wachowiak 2001, Koźmiński, Piotrowski 2006).

\section{Elementy wymiaru kompetencyjnego współczesnego menedżera}

Umiejętności menedżerskie to przede wszystkim umiejętności związane z działalnością zawodową i społeczną. Umiejętności zawodowe łączą się z kwalifikacjami, jakich wymaga się od menedżerów zajmujących stanowiska kierownicze na poszczególnych poziomach zarządzania, i z nieustannym ich rozwijaniem i doskonaleniem. Umiejętności społeczne menedżera związane są z poszukiwaniem i doborem ludzi, w szczególności na stanowiska kierownicze, i kształtowaniem relacji międzyludzkich.

Na znaczenie wrodzonych zdolności i nabytych umiejętności kierowniczych u menedżerów zwrócił już uwagę F.W. Taylor, oddzielając umiejętności kierownicze od umiejętności technicznych. Zauważył on, że wraz ze wzrostem poziomu zarządzania, w organizacji zwiększa się znaczenie umiejętności kierowniczych. A od czasu badań H. Fayola umiejętności kierownicze sprawnych i efektywnych menedżerów systematycznie są poddawane analizie i ocenie, co przyczyniło się do powstania wielu ich typologii. Jedną z wcześniejszych typologii umiejętności kierowniczych (menedżerskich) jest podział R.L. Katza. Wyróżnił on techniczne, społeczne i koncepcyjne umiejętności menedżerskie. Rola i znaczenie wyodrębnionych grup umiejętności menedżerskich są różne, zależne od hierarchicznego poziomu zarządzania. Na przykład umiejętności techniczne są niezbędne w rozwiązywaniu konkretnych zadań operacyjnych czy w szkoleniu pracowników; wymaga się ich od kierowników pierwszej linii (technicznego poziomu zarządzania). Umiejętności społeczne (interpersonalne) są istotne w kształtowaniu właściwych relacji kierownika z podwładnymi, klientami i innymi partnerami instytucji. Umiejętności te $\mathrm{w}$ szczególności powinni posiadać kierownicy średniego organizacyjnego poziomu zarządzania. Na najwyższym hierarchicznie poziomie zarządzania (strategicznym) najważniejsze są umiejętności koncepcyjne, niezbędne w procesie planowania, organizowania działań, motywowania pracowników i twórczego rozwiązywania problemów, także w perspektywicznym horyzoncie czasowym, jak również w nawiązywaniu i utrzymywaniu różnorodnych relacji z otoczeniem - społeczeństwem (Żukowski 1989, Rakowska, SitkoLutek 2000, Kuc 2004, Wołowiec 2009).

Na konkretyzację umiejętności menedżerskich poważny wpływ wywarły badania $\mathrm{D}$. Whettena i K. Camerona, uznane za jedne z najbardziej nowatorskich. Wyróżnili oni dziewięć kluczowych umiejętności menedżerskich i pogrupowali je w dwie kategorie: umiejętności osobiste (doskonalenie samoświadomości, kierowanie stresem, twórcze rozwiązywanie problemów) i umiejętności interpersonalne (ustanawianie wspierającej komunikacji, zdobywanie wiedzy i wpływów, kierowanie konfliktami, skuteczne delegowanie, motywowanie innych, grupowe podejmowanie decyzji) (Rakowska, Sitko-Lutek 2000, s. 23). Na podstawie własnych badań wykorzystując wyniki badań D. Whettena i K. Camerona oraz innych badaczy - wyróżniłem, rozszerzyłem i syntetycznie opisałem czternaście kluczowych umiejętności menedżerskich; przedstawiono je na ryc. 1 .

Wyodrębnienie i rozwijanie menedżerskich umiejętności osobistych jest potrzebne dla głębszego zrozumienia własnych emocji i zachowań, a więc poznania samego siebie. 
Przejawiają się one w bezpośrednich kontaktach z podwładnymi, klientami i innymi partnerami organizacji. Do menedżerskich umiejętności osobistych należy zaliczyć:

- rozwijanie i doskonalenie samoświadomości,

- kierowanie emocjami w sytuacjach trudnych i stresie,

- innowacyjne i twórcze rozwiązywanie problemów,

- zdobywanie i rozwijanie nowych umiejętności osobistych,

- twórcze wykorzystywanie wiedzy specjalistycznej,

- dzielenie się nabytą wiedzą i doświadczeniem,

- budowanie autorytetu osobistego i własnego wizerunku (por. Bartkowiak, Januszek 1999, Rakowska, Sitko-Lutek 2000, Stoner, Freeman, Gilbert 2001, Wachowiak 2001, Małyk-Musiał 2005, Żukowski 2005).

Ryc. 1. Kluczowe umiejętności menedżerskie

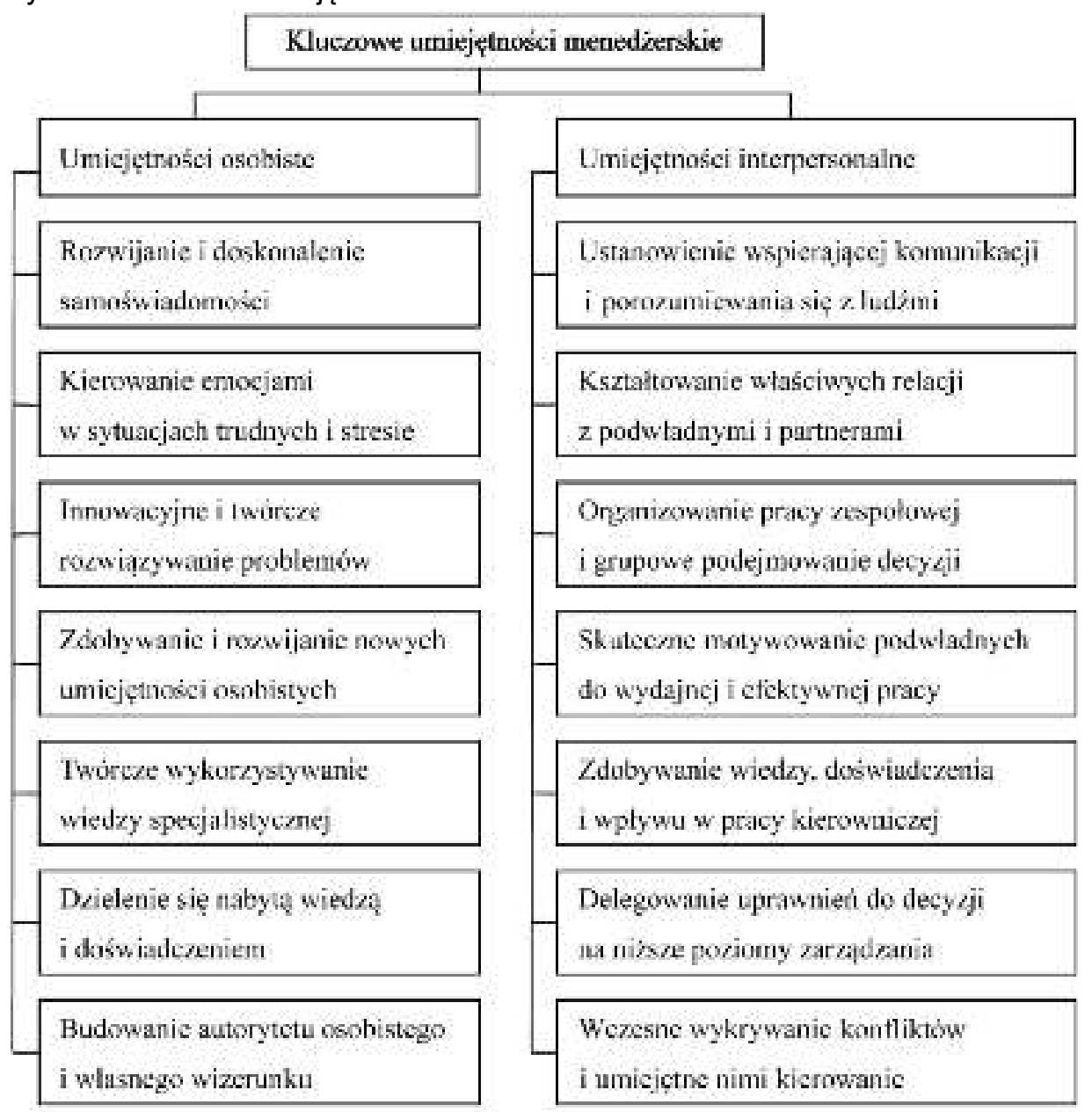

Źródło: opracowanie autora na podstawie: Bartkowiak, Januszek 1999, Rakowska, Sitko-Lutek 2000, Stoner, Freeman, Gilbert 2001, Wachowiak 2001, Małyk-Musiał 2005, Żukowski 2005, 2008.

Wyróżnienie i rozwijanie menedżerskich umiejętności interpersonalnych jest konieczne, umożliwiają one bowiem menedżerowi nawiązywanie i utrzymywanie właściwych relacji oraz organizowanie współpracy i współdziałania z podwładnymi, innymi członkami organizacji i klientami, kontrahentami i innymi partnerami, a także instytucjami, co ułatwia i usprawnia realizację zadań własnych (Wachowiak 2001). Do menedżerskich umiejętności interpersonalnych zaliczyć należy:

- ustanowienie wspierającej komunikacji i porozumiewania się z ludźmi,

- kształtowanie właściwych relacji z podwładnymi i partnerami, 
- organizowanie pracy zespołowej i grupowe podejmowanie decyzji,

- skuteczne motywowanie podwładnych do wydajnej i efektywnej pracy,

- zdobywanie wiedzy, doświadczenia i wpływu w pracy kierowniczej,

- delegowanie uprawnień do decyzji na niższe poziomy zarządzania,

- wczesne wykrywanie konfliktów i umiejętne nimi kierowanie (por. Bartkowiak, Januszek 1999, Rakowska, Sitko-Lutek 2000, Stoner, Freeman, Gilbert 2001, Małyk-Musiał 2005, Żukowski 2008).

Rozwijanie i doskonalenie samoświadomości - zaliczone do grupy umiejętności osobistych menedżera - wymaga głównie identyfikacji, pogłębionej analizy i oceny osobistych mocnych i słabych stron oraz świadomego uwzględniania własnego potencjału w pracy kierowniczej. Kierowanie emocjami w sytuacjach trudnych i stresie wiąże się z umiejętnościami redukowania napięcia emocjonalnego i radzenia sobie ze stresem oraz wykorzystaniem doświadczenia z tego zakresu do doskonalenia samoświadomości. Innowacyjne i twórcze rozwiązywanie problemów wymaga umiejętnego łączenia myślenia analitycznego i racjonalnego z kreatywnym, by skutecznie, w sposób nowatorski rozwiązywać problemy w procesie zarządzania. Zdobywanie i rozwijanie nowych umiejętności osobistych wymaga zdolności pozyskiwania, uzupełniania i rozwijania nowych umiejętności specjalistycznych, zwłaszcza osobistych menedżerskich, promowania innowacji, usprawniania procesów, stwarzania nowych możliwości oraz kształtowania nawyków koniecznych do akceptowalnego wypełniania obowiązków służbowych w pracy kierowniczej. Twórcze wykorzystywanie wiedzy specjalistycznej wymaga, by menedżer w pracy kierowniczej nie tylko sam żywo interesował się wszelkimi nowościami i twórczo wykorzystywał własną wiedzę ogólną i specjalistyczną, ale też w pełni korzystał z zasobów intelektualnych zarówno indywidualnych pracowników, jak i zespołów pracowniczych w procesie tworzenia zysku organizacji, a także stwarzał odpowiednie nastawienie psychiczne do kreatywnego wykorzystywania przez pracowników w praktyce wiedzy naukowej i nabytych umiejętności, jak również odpowiednio motywował (nakłaniał) podległy mu personel do bezkonfliktowego wprowadzania nowych rozwiązań naukowych do praktyki (projekty, patenty, licencje i inne rozwiązania). Dzielenie się nabytą wiedzą i doświadczeniem wymaga, by menedżer w stosowny sposób przekazywał i rozpowszechniał zdobytą wiedzę i posiadane doświadczenie wśród swoich podwładnych, zwłaszcza kierowników niższego poziomu zarządzania, stwarzał realne możliwości kreatywnej pracy podwładnych, jak również zachęcał ich do samodzielnego studiowania nowych rozwiązań dotyczących zagadnień związanych z pracą zawodową (stanowiskiem pracy). Dzięki temu umiejętności pojedynczych pracowników i zespołów pracowniczych zostają przekształcone w zasoby wiedzy służące całej organizacji; zwiększa się doświadczenie podwładnych, a to sprzyja wdrażaniu do praktyki kierowniczej wszelkich innowacji. Budowanie autorytetu osobistego i własnego wizerunku są istotnymi umiejętnościami osobistymi każdego menedżera, wpływającymi znacząco na skuteczność zarządzania. Oprócz autorytetu formalnego, dającego prawo do rozkazywania (wydawania poleceń), lecz nie zawsze wymuszającego posłuszeństwo, menedżer powinien mieć autorytet osobisty. Zdobywa się go przez poszerzanie i doskonalenie wiedzy i umiejętności menedżerskich, taktowne postępowanie, prawdomówność, sprawiedliwość, uczciwość, życzliwość, kulturę osobistą i inne pozytywne cechy osobowe, a także przez stosowanie metod i technik zarządzania oraz przejawianie stylu kierowania adekwatnie do okoliczności oraz warunków zarządzania. Powyższe przymioty i działania oraz zdobywanie doświadczenia zawodowego (profesjonalnego) i rozwijanie umiejętności kierowniczych, a także posługiwanie się wpływem społecznym sprzyjają również tworzeniu pozytywnego własnego wizerunku menedżera (Bartkowiak, Januszek 1999, Rakowska, Sitko-Lutek 2000, Stoner, Freeman, Gilbert 2001, Banaszek 2006, Żukowski 2006, Kubik 2008). 
Sprawne zarządzanie to też sztuka jasnego i zwięzłego formułowania celów oraz umiejętnego komunikowania się z ludźmi. W grupie umiejętności interpersonalnych istotne znaczenie ma ustanowienie wspierającej komunikacji i skutecznego porozumiewania się z ludźmi, wymagające od menedżera umiejętności organizowania sprawnego systemu porozumiewania się z innymi osobami, szybkiego i skutecznego odbierania i przekazywania informacji pracownikom i partnerom instytucji, rozumienia ich i wpływania na ich postępowanie, uważnego słuchania innych, zwięzłego i logicznego formułowania myśli i prezentacji zagadnień wymagających rozwiązania. Profesjonalny menedżer, chcąc skutecznie spełniać funkcje zarządzania i sprawnie realizować zadania, powinien dążyć do tego, by komunikacja w organizacji była konstruktywna. Kształtowanie właściwych relacji z podwładnymi i partnerami, organizowanie pracy zespołowej i grupowe podejmowanie ważniejszych decyzji wymaga od menedżera umiejętności ustanawiania przejrzystych zasad kształtowania zawodowych relacji z podwładnymi i stosunków z partnerami instytucji. Dotyczy to także umiejętności organizowania i prowadzenia zebrań, publicznej prezentacji problemów, koncepcji ich rozwiązań itp. Menedżer realizuje cele i większość zadań instytucji nie przez osobiste ich wykonanie, lecz za pośrednictwem innych ludzi, podwładnych. Jedną więc z zasadniczych umiejętności, jakiej wymaga się od współczesnego menedżera, jest umiejętność skutecznego motywowania i zachęcania podwładnych do twórczej, wydajnej i efektywnej pracy, z wykorzystaniem odpowiednio dobranego zestawu narzędzi motywacyjnych. Menedżer musi mieć taki wpływ na podwładnych, aby zachowywali się oni zgodnie z jego oczekiwaniami i realizowali założone cele i zadania instytucji. Zdobywanie wiedzy, doświadczenia i wpływu w pracy kierowniczej wymaga umiejętności weryfikowania zdobytej wiedzy specjalistycznej w praktycznym działaniu, utrwalania umiejętności i nawyków przydatnych w pracy kierowniczej, zdobywania wpływu społecznego i autorytetu u innych w celu zwiększenia sprawności zarządzania. Umiejętność skutecznego delegowania uprawnień do decyzji na niższe poziomy zarządzania wymaga umiejętności rozpoznawania problemów zarządczych i określenia, jakie zadania, kiedy i komu można przydzielić, jakie można przekazać uprawnienia i kompetencje oraz jaki zakres odpowiedzialności będzie stosowny do przydzielonych zadań, by zarządzanie było sprawne i efektywne. Pracownicy organizacji mają różne życzenia, potrzeby i oczekiwania, w związku z tym prezentują różne postawy wobec organizacji, które mogą pozostawać w sprzeczności z jej celem i prowadzić w niej do sytuacji konfliktowych. W organizacji są one nieuniknione i mogą znacząco ograniczyć efektywność jej działania, jeśli w odpowiednim czasie nie zostaną zidentyfikowane, rozpoznane i rozwiązane. Stąd ważną umiejętnością menedżera jest wykrywanie konfliktów i umiejętne kierowanie nimi, a więc wczesne ich wykrywanie, rozwiązywanie i usuwanie, jak również radzenie sobie z emocjami w takich sytuacjach (Bartkowiak, Januszek 1999, Rakowska, Sitko-Lutek 2000, Stoner, Wankel 2001, Banaszek 2006, Żukowski 2006).

Zaprezentowany wyżej profesjonalny wzorzec umiejętności współczesnego menedżera zawiera kluczowe, osobiste i interpersonalne umiejętności menedżerskie, których można się nauczyć podczas treningu przez kształtowanie nowych postaw i zachowań. W tej prezentacji pominięto umiejętności techniczne, których nabywa się w nieco inny sposób i które w mniejszym stopniu dotyczą kształtowania zachowań menedżera. Znaczenie zasobu wiedzy i zespołu umiejętności menedżerskich dla sprawności i efektywności zarządzania systematycznie rośnie. Ma to związek z nasilaniem się procesów globalizacji i integracji europejskiej w skali światowej, a także z coraz większą złożonością procesów technologicznych (technicznych), ekonomicznych, społecznych i ekologicznych oraz kulturowych, zachodzących we współczesnych organizacjach i tworzącym się społeczeństwie informacyjnym, gdzie w podnoszeniu konkurencyjności gospodarki i społeczeństwa wiedza i zasoby intelektualne jednostek ludzkich i zespołów pracowniczych znaczą najwięcej. 
Ch. Prahalad wyróżnia następujące umiejętności i cechy osobowe menedżera:

- umiejętność myślenia koncepcyjnego i systemowego,

- umiejętność działania w wielokulturowym otoczeniu,

- gotowość do ustawicznego uczenia się,

- zespół pozytywnych cech osobowych i wysokich standardów zachowań.

Każdy menedżer powinien umieć myśleć koncepcyjnie i systemowo i dostrzegać zarówno związki między poszczególnymi elementami systemu, jak i myśleć perspektywicznie i ogarniać w przestrzeni problemowej całość zagadnień kierowniczych. Powinien także mieć zdolność syntezy informacji zarówno o znaczeniu strategicznym, jak i operacyjnym, łączenia umiejętności analitycznych z własną intuicją i doświadczeniem oraz wyważania interesu prywatnego i dobra wspólnego. Ważną umiejętnością menedżera w warunkach globalizacji jest umiejętność działania w wielokulturowym otoczeniu; bardzo pomocna jest tu znajomość całej różnorodności form kultury i języków obcych. Globalizacja zarządzania powoduje konieczność myślenia w kategoriach międzykulturowych i uwzględniania faktu, że w innych kulturach niekoniecznie musi obowiązywać ten sam system celów i wartości, w którym został wychowany. Praca menedżera wymaga od niego ciągłego doskonalenia wiedzy ogólnej i specjalistycznej, zdobywania i rozwijania nowych umiejętności kierowniczych. Menedżerowie muszą stale być gotowi do przyjmowania nowych idei, technologii, konstrukcji, dobrych praktyk gospodarczych oraz wartości kulturowych, muszą poszukiwać możliwości permanentnego uczenia się. Obowiązkiem menedżerów jest ustalanie wymaganych przez instytucję standardów wartości i zachowań. Stąd konieczne jest stałe doskonalenie, związane z dogłębną znajomością instytucji i jej obszaru działania, dążeniem do jak najwyższego poświęcenia w pracy i jej efektywności, odpowiedzialnością za swoje działania i pracę podwładnych, wrażliwością na sprawy ludzkie, stosunki międzyludzkie i międzykulturowe problemy, tolerancja wobec różnych kultur oraz pobudzanie i wspieranie rozwoju współpracowników i podwładnych (Szczupaczyński 1998, Kuc 2004, Banaszek 2006, Żukowski 2008).

Nasza gospodarka mocno odczuwa niedostatek zdolnych i nowocześnie wykształconych menedżerów, o właściwych postawach etyczno-moralnych. Obecnie zarządzanie polega bardziej na formalnie zajmowanym stanowisku niż na władzy intelektu i wysokich kwalifikacji menedżerskich. Wiele stanowisk zajmują menedżerowie o niewysokich kwalifikacjach, niezbyt szerokich horyzontach myślowych i potencjale umysłowym. Brakuje im nie tylko silnej osobowości, ale i podstawowej wiedzy i umiejętności profesjonalnych, inteligencji, wyobraźni i talentu. Przyszłość jednak wymaga innego, bardziej innowacyjnego i kreatywnego modelu menedżera. Powinien on bardziej przewodzić niż zarządzać (Witkowski, red., 1996). Potrzebuje nie tylko wizji, autorytetu, energii, wyobraźni i zdolności formułowania strategii, lecz także umiejętności uruchamiania tzw. miękkich czynników, jak życzliwa atmosfera w pracy, skuteczne motywowanie podwładnych, przyjazne nastawienie do zmian i postępu gospodarczo-społecznego, informacyjno-kulturowego, empatii, przystępności, oryginalności, innowacyjności, przedsiębiorczości. A zatem menedżer musi odznaczać się głęboką wiedzą i opanowaniem całego zespołu umiejętności z zakresu nowoczesnego zarządzania, inteligencją, twórczą wyobraźnią, odwagą, rozwiniętą intuicją, talentem, a także silną wolą, wysokim poziomem aspiracji i postawy etyczno-moralnej, podejmowaniem decyzji i działań, które nie tylko przyczynią się do powiększania własnych zysków, ale również do pomnażania dobrobytu społecznego (dobra wspólnego).

Od menedżera, jak podkreśla P.F. Drucker (1994): „(...) oczekuje się przede wszystkim, że doprowadzi do zrobienia tego, co należy. A to po prostu oznacza, że oczekuje się od niego skuteczności (...)” w działaniu. Ośrodek Kreatywnego Przywództwa w Stanach Zjednoczonych na 
podstawie dwudziestoletniej współpracy z tysiącami menedżerów reprezentujących różnorodne organizacje sformułował zespół cech (predyspozycji) skutecznego menedżera. Są to:

- wzmożona świadomość własnego potencjału; kompleksowa znajomość swoich mocnych i słabych stron, sposobu, w jaki są one postrzegane przez innych i w jaki oddziałują na innych;

- zachęcanie innych do przekazywania informacji zwrotnej, dzięki czemu uzyskuje się wiedzę o sobie samym, pomocną przy zmianach działania;

- chęć do zdobywania wiedzy, która umożliwia zmianę własnej perspektywy patrzenia i postępowania, pobudza kreatywność i pozwala myśleć o różnych sprawach w inny sposób;

- umiejętność integrowania pracy z życiem; przewodzenie i życie są ze sobą bardzo silnie związane, obowiązki wobec rodziny oraz społeczności lokalnej należy zintegrować z obowiązkami wynikającymi pracy, menedżer-przywódca musi dążyć do tego, by poczuć się pewnie na tych wszystkich obszarach oraz skorelować je ze sobą;

- postawa szacunku wobec odmienności innych ludzi; aby działać efektywnie w otoczeniu menedżer-przywódca musi mieć świadomość i wrażliwość na istniejące różnice między ludźmi (językowe, w zwyczajach, obyczajach i kulturze) oraz systemach wartości wyznawanych przez innych ludzi.

Organizacja z przekonań i entuzjazmu przywódcy-lidera ma czerpać dla siebie energię do działania. Menedżerowie więc muszą stosować zarządzanie wyzwalające (ang. Liberation Management), które wynika z elastyczności organizacji i pozytywnego nastawienia do wysiłku pracowników realizujących konkretne cele (zadania).

Rodzi się pytanie o sylwetkę (model) menedżera: jaki on jest i jakie powinien mieć kompetencje, umiejętności kierownicze, aby mógł sprostać wymaganiom współczesnego zarządzania organizacją. Obecni menedżerowie mają przeważnie profesjonalne wykształcenie średnie lub wyższe z zakresu ekonomii lub zarządzania, albo wykształcenie techniczne z danej branży czy prawnicze. Od współczesnego menedżera wymaga się stałego podnoszenia wiedzy ogólnej i specjalistycznej oraz doskonalenia umiejętności kierowniczych. Jego zadania dotyczą przede wszystkim analizy rynku i innych składników otoczenia, doskonalenia systemu informacyjnego, zwłaszcza informatycznego, planowania i organizacji marketingu oraz promocji produktów. Menedżer jest skuteczny i osiąga powodzenie w pracy kierowniczej, jeśli oprócz wiedzy ogólnej ma kwalifikacje zawodowe, a zwłaszcza umiejętności menedżerskie.

Wśród wielu ujęć spotykanych w literaturze przedmiotu można wyróżnić umiejętności kierownicze: techniczne, interpersonalne, koncepcyjne, analityczne i diagnostyczne (Drucker 1994, Bartkowiak, Januszek 1999, Rakowska, Sitko-Lutek 2000, Stoner, Freeman, Gilbert 2001, Wachowiak 2001, Żukowski 2006, Kubik 2008).

Umiejętności techniczne są to umiejętności niezbędne do wykonywania pracy (zawodu) lub zrozumienia sposobu, w jaki wykonywana jest konkretna praca w ramach instytucji. Inżynierowie projektanci, technologowie, księgowi i inni specjaliści dysponują umiejętnościami technicznymi niezbędnymi do wykonywania odpowiednich prac i zawodów. Dochodzą oni do podstawowych umiejętności technicznych, kończąc odpowiednie studnia wyższe. Następnie nabierają doświadczenia w rzeczywistych sytuacjach w pracy, doskonaląc nabyte umiejętności, aż staną się rzeczywiście skutecznymi menedżerami, technologami, specjalistami z rachunkowości itp., stosownie do kwalifikacji. Podobnie np. menedżer najwyższego poziomu zarządzania odpowiedzialny za marketing $\mathrm{w}$ dużej organizacji prawdopodobnie zaczynał pracę na stanowisku kierownika działu sprzedaży. Tak więc umiejętności techniczne są niezbędne do zrozumienia lub wykonania określonych zadań (prac) (Rakowska, Sitko-Lutek 2000, Kuc 2004).

Umiejętności interpersonalne menedżera to umiejętności współpracy i współdziałania z ludźmi oraz oddziaływania na nich. Menedżerowie spędzają dużo czasu na spotkaniach 
i rozmowach z ludźmi, zarówno wewnątrz organizacji, jak i poza nią. $Z$ tych względów menedżer musi mieć również zdolności do nawiązywania kontaktów i łączności z pojedynczymi osobami i zespołami pracowniczymi, rozumienia ich i skutecznego motywowania do twórczej, wydajnej i efektywnej pracy. W miarę jak menedżer awansuje w pracy zawodowej, musi on umieć skutecznie współpracować z podwładnymi i innymi kierownikami, a także z osobami znajdującymi się na wyższych poziomach zarządzania instytucją. Ze względu na wielość i różnorodność ról, jakie muszą odgrywać menedżerowie, powinni oni umieć współpracować z dostawcami, kooperantami, inwestorami, klientami i innymi partnerami spoza danej organizacji. Tak więc umiejętności interpersonalne to umiejętności organizowania skutecznej komunikacji - łączności, nawiązywania kontaktów i współpracy, rozumienia potrzeb i motywowania zarówno pojedynczych osób, jak i zespołów pracowniczych do twórczej, wydajnej i efektywnej pracy (Witkowski 1996, Bartkowiak, Januszek 1999, Stoner, Freeman, Gilbert 2001, Żukowski 2006).

Umiejętności koncepcyjne menedżera polegają na zdolności do analizowania i rozwiązywania problemów, przewidywania przyszłych wydarzeń i podejmowania trafnych decyzji. Menedżerowie powinni posiadać określony potencjał intelektualny, który pozwoli im spostrzegać złożoność funkcjonowania instytucji i zmienność elementów jej otoczenia, zrozumieć sposób, w jaki poszczególne, różnorodne składniki organizacji, współpracując ze sobą, łączą się w jedną, solidną, funkcjonalną całość, i ujmować ją w sposób kompleksowy. Takie ujęcie pozwala myśleć i działać strategicznie, w szerokiej skali i dłuższych horyzontach czasowych oraz podejmować na tej podstawie decyzje strategiczne i operacyjne służące organizacji jako całości. Tak więc umiejętności koncepcyjne to umiejętności związane z wyobraźnią i ze zdolnością do myślenia abstrakcyjnego.

Umiejętności analityczne i diagnostyczne sprawnego menedżera - według A. Pocztowskiego i K. Kubik - to umiejętności umożliwiające mu wyodrębnienie istotnych składników rozważanego problemu, rozpoznanie ich w różnych aspektach (społecznym, ekonomicznym, prawnym, finansowym, ekologicznym, kulturowym) i postawienie stosownej diagnozy oraz obmyślenie i podjęcie stosownej decyzji i działań z uwzględnieniem istniejących okoliczności i zasobów. Menedżer analizuje, rozpoznaje, diagnozuje powstały problem zarządczy w instytucji, bada jego symptomy, określa przyczyny i opracowuje na tej podstawie racjonalne jego rozwiązanie (Coates 1998, Rakowska, Sitko-Lutek 2000, Wachowiak 2001, Zawiślak 2003, Żukowski 2006, Kubik 2008).

Wszystkie wyżej wyodrębnione rodzaje umiejętności kierowniczych menedżer musi opanować, aby zarządzanie było skuteczne i efektywne. Już H. Fayol i R. L. Katz wskazywali, że znaczenie tych umiejętności jest różne w zależności od poziomu zarządzania. Rola umiejętności technicznych jest szczególnie ważna na najniższym poziomie zarządzania, a umiejętności koncepcyjnych - na najwyższym. Jednak kierownicy wszystkich poziomów zarządzania muszą mieć rozwinięte umiejętności interpersonalne, bez których nie można efektywnie kierować ludźmi (Stoner, Freeman, Gilbert 2001). Nieco odmiennego zdania jest H. Mintzberg, który krytykuje tradycyjny opis roli menedżera. Jego zdaniem menedżer jest przeciążony obowiązkami i w zasadzie nie potrafi ich skutecznie delegować na niższe poziomy zarządzania. Jest więc przepracowany, wiele zadań wykonuje samodzielnie, a siłą rzeczy jego pracę cechuje wycinkowość. Tak było i jest obecnie, że czynni menedżerowie są ludźmi o bardzo różnych cechach osobowości, różnym wykształceniu, różnych umiejętnościach i zdolnościach menedżerskich i różnym doświadczeniu zawodowym. W takich okolicznościach trudno jest opracować uniwersalną sylwetkę sprawnego menedżera, chociaż np. R. Kreitner stwierdza, że: sukces menedżera = potencjał x motywacje x możliwości (Szczupaczyński 1998). 
Potencjał to wiedza ogólna i specjalistyczna, umiejętności menedżerskie, doświadczenie, pożądane cechy osobowościowe menedżera, wyznawany system celów i wartości oraz przestrzeganie w postępowaniu zasad etyczno-moralnych. Menedżer musi być odpowiednio umotywowany do rozwoju zawodowego, poszerzania swojej wiedzy i umiejętności, zdobywania doświadczenia. Do sprawnego działania i osiągnięcia sukcesu w biznesie niezbędne są również możliwości, tzn. określone stanowisko, otwarta ścieżka awansu zawodowego, wykwalifikowany personel i odpowiednie zaplecze techniczne i informacyjne, a niekiedy także badawcze.

\section{Wymiar osobowościowy}

\section{Typologie menedżerów}

Na temat cech osobowościowych menedżera i stawianych mu wymagań istnieje wiele różnych poglądów, opinii i naukowych opracowań. Wynikają z nich istotne różnice postulowanych modeli osobowości menedżera i sposobów jego zachowania (Kubik 2008).

Amerykański psycholog zarządzania H. Leavitt zaproponował bardzo użyteczną typologię menedżerów. Oto ona:

- menedżer wizjoner jest to osoba śmiała, charyzmatyczna, oryginalna, często ekscentryczna, błyskotliwa i bezkompromisowa, proponuje całkowite zerwanie z przeszłością i wejście na nowe tereny działania, jest obdarzony intuicją inspirującą zwolenników i często kieruje się wyczuciem (instynktem);

- menedżer analityk zajmuje się liczbami i faktami, a nie opiniami, jest racjonalistą, rachmistrzem i kontrolerem, widzi świat w barwach czarnych i białych, uważa, że na wszystko jest właściwa odpowiedź, potrafi za pomocą liczb i rachunkowości (finansowo) kontrolować olbrzymie korporacje, jest systematyczny i posiada umiejętności wykorzystywania systemów kontroli;

- menedżer wykonawca jest pragmatykiem odnoszącym sukcesy w działaniu, we wdrażaniu planów i projektów oraz rozwiązywaniu trudności, z reguły nie jest obciążony skłonnością do wizjonerstwa czy nadmiernej analizy, dąży do podporządkowywania podwładnych swojej woli.

Na Zachodzie praktyka zarządzania wykształciła pewne europejskie wzorce osobowościowe menedżerów:

- menedżerowie odważni są dobrze przygotowani, ambitni, identyfikują się z organizacją i zmierzający do pożądanej jej odnowy, dążą do zaprezentowania się jako kierownicy wartościowi, dojrzali; ich odwaga wynika z wiedzy, umiejętności i kompetencji kierowniczych oraz doświadczenia;

- menedżerowie wyzywający są niezadowoleni z faktycznego stanu rzeczy, przeciwstawiają się istniejącej strukturze działań w organizacji, pragną zmian, odnowy, są jednak przeciwnikami przekazywania kompetencji;

- menedżerowie niezadowoleni oddalają się od organizacji, odrzucają zastany (istniejący) porządek rzeczy, lecz nie są zdolni do wypracowania programu zmian na lepsze, nie mają ambicji ani większej chęci działania, nie identyfikują się z organizacją, utrzymują wobec niej dystans i odgradzają się od panujących w niej uciążliwości;

- menedżerowie konformiści akceptują organizację w zastanym kształcie i porządku rzeczy, uważają istniejące rozwiązania za najkorzystniejsze (optymalne), bronią jej porządku i chcą, aby była taka sama w przyszłości; ich motywacją jest dążenie do bycia akceptowanym w organizacji (por. Penc 2001). 
Zgodnie $\mathrm{z}$ opiniami wielu specjalistów, wymagania wobec menedżerów ciągle rosną. W związku z tym formułuje się zespoły cech, których spełnienie wymaga się od menedżera. Na przykład amerykańska firma doradztwa personalnego Kom i Ferry - na podstawie badań przeprowadzonych w grupie około 1500 amerykańskich, japońskich i europejskich menedżerów o najwyższych kwalifikacjach - uważa, że menedżerowie muszą być przede wszystkim entuzjastami, powinni inspirować, dodawać otuchy, być otwarci i kreatywni oraz dawać przykład etycznego postępowania. Zdaniem jej ekspertów, idealnym menedżerem jest kosmopolita ze świetnym wykształceniem ogólnym, tolerancyjny wobec różnych kultur, sprawny w pracy zespołowej, o niezależnym sposobie myślenia.

\section{Osobowość menedżera}

Osobowość każdego człowieka, jako wartość niepodzielna i jedyna w swoim rodzaju, jest zorganizowaną strukturą cech indywidualnych, wyznawanych wartości i określonych postaw, przejawiających się w sposobach zachowania. Decyduje ona o elastyczności przystosowania się, adaptacji danej jednostki ludzkiej do otoczenia (społeczeństwa). Osobowość menedżera tworzy zintegrowana całość m.in. takich wyróżnionych elementów, jak: cechy fizyczne, temperament, uzdolnienia intelektualne, zainteresowania i zamiłowania, wyznawany system wartości, przejawiane postawy społeczne, sposoby wyrażania myśli, styl bycia i inne cechy (por. Stoner, Wankel 2001).

Temperament jest zespołem cech zachowania człowieka przejawiających się w sile i szybkości reagowania na różne sytuacje; w poważnym stopniu kreuje on osobowość menedżera. Uzdolnienia intelektualne obejmują cały zespół różnic intelektualnych, np. rozwinięte poczucie humoru wymaga szybkiego zrozumienia przenośni czy aluzji. Zainteresowania i zamiłowania związane są z ludzką aktywnością, wyznaczają zasadniczy kierunek działania i wpływają na powodzenie w pracy zawodowej. System wartości tworzy wiele elementów składowych należących do zagadnień filozoficznych. Sposoby wyrażania myśli i styl bycia przejawiają się w relacjach z innymi ludźmi.

Wymienione wyżej składniki (właściwości) nie wyczerpują oczywiście wszystkich cech osobowości pożądanych we wzorcu idealnego menedżera. Należy je uzupełnić wieloma innymi cechami, jak: silna wola, prawy charakter, szczerość i godność osobista, spostrzegawczość i kreatywność, chęć uczenia się i doskonalenia, dzielenia się wiedzą i doświadczeniem, a także ambicja, zdyscyplinowanie, punktualność. Zintegrowana i pozytywnie oceniana osobowość menedżera jest znaczącym źródłem władzy, wpływ i oddziaływanie władcze menedżera na inne osoby związane są bowiem w istotny sposób z cechami jego osobowości. Jak dana osobowość jednostki ludzkiej sprawdza się w praktycznym działaniu w określonym zespole pracowniczym, ostatecznie w dużym stopniu zależy od uznawanego systemu wartości, cech osobowości, a także od otoczenia, w którym pracuje - członków zespołu, stopnia zaspokajania ich potrzeb i oczekiwań, jak też warunków, w jakich dany zespół funkcjonuje (m.in. warunków zarządzania).

Zgodnie z opinią E. H. Scheina, menedżerowie-liderzy powinni mieć:

- wysoki poziom percepcji i zrozumienia otaczającej rzeczywistości i samych siebie;

- wysoki poziom motywacji, umożliwiający aktywną partycypację w procesie uczenia się i zmian;

- wielką siłę emocjonalną, pozwalającą pokonywać niepokoje i trudności;

- umiejętność analizy przesłanek kulturowych, identyfikacji tych rozwiązań, które mają rację bytu i tych, które funkcjonują niewłaściwie, a także analizy procesów rozwijających kulturę organizacji pracy; 
- chęć i umiejętność angażowania innych pracowników i pozyskiwania ich aktywnego udziału w rozwiązywaniu problemów i wykonywaniu zadań;

- chęć i umiejętność dzielenia się władzą i uprawnieniami do kontroli zgodnie z wiedzą i umiejętnościami ludzi (przekazywanie kompetencji na niższe poziomy zarządzania) (por. Wachowiak 2001).

W studium opracowanym przez Międzynarodową Agencję Pośrednictwa Menedżerów (TASA) w Brukseli na podstawie ankiety przeprowadzonej wśród najlepszych menedżerów różnych narodowości i zawodów, ustalono, że sprawny menedżer powinien:

- być komunikatywnym, doskonale informować;

- być praktykiem znającym realia - dzięki talentowi i praktycznemu doświadczeniu;

- być zdolnym do stworzenia systemu z tego, co dobrze funkcjonuje;

- być wizjonerem o nieustającej motywacji, kimś, kto potrafi skupić wokół siebie zespół ludzi przekształcających jego wizję w rzeczywistość;

- wyczuwać zmiany i odpowiednio na nie reagować;

- podejmować decyzje, które mogą okazać się słuszne dopiero w przyszłości;

- utrzymywać równowagę między poszanowaniem podwładnych a konsekwencją podejmowanych decyzji;

- być cierpliwym, zdolnym do wysłuchiwania innych i chętnym do udzielania pomocy;

- być otwartym na wszystkie pomysły i poglądy;

- umiejętnie reprezentować organizację wobec osób z zewnątrz.

Na uwagę zasługuje to, że pożądane cechy osobowe (osobowość) menedżerów w poszczególnych krajach różnią się między sobą. Na przykład dla Amerykanów najważniejsza jest kondycja fizyczna i psychiczna, a dla Belgów i Francuzów nie ma ona większego znaczenia, natomiast umiejętność wzbudzania zaufania zajmuje u nich jedno z pierwszych miejsc, a u Amerykanów - ostatnie miejsce. Mentalność menedżerów poszczególnych krajów także się różni. Brytyjczycy zaczynają spotkanie od ogólnej pogawędki, Francuzi traktują porządek dzienny jako ogólną inspirację, Niemcy uważają za oczywiste, że trzeba się trzymać programu i natychmiast przystępować do rzeczy. Wśród menedżerów niemieckich Francuzi uchodzą za chaotycznych i niedostatecznie systematycznych, choć szczególnie efektywnych w rozwiązywaniu problemów techniki, zwłaszcza automatyzacji. Wszystkich zachodnich menedżerów cechuje wysoki poziom profesjonalizmu.

Nie wypracowano jeszcze solidnej osobowościowej charakterystyki polskich menedżerów; trudno jest też stwierdzić, czy są oni dobrze przygotowani do podejmowania wyzwań, jakie stoją przed polskim managementem w warunkach globalizacji i integracji, choć podjęto pewne próby w tym zakresie. Badania cech osobowych (osobowości) polskich menedżerów, przeprowadzone przez naukowców (psychologów) z Uniwersytetu Wrocławskiego, pozwoliły określić (wyodrębnić) następujące ich słabości:

- niechęć do brania odpowiedzialności,

- powolność w podejmowaniu decyzji,

- spora emocjonalność w stosunkach międzyludzkich,

- brak ducha innowacyjności,

- mała elastyczność działania,

- preferowanie poczucia bezpieczeństwa,

- stosunkowo mała skuteczność i efektywność działania (por. Szczupaczyński 1998).

Słabości te są jednak równoważone przez wysoką inteligencję, kreatywność, zdolność do adaptacji nowych metod i technik zarządzania oraz chęć uczenia się i doskonalenia. Jednakże te zalety widoczne są zwłaszcza w organizacjach typu joint venture i prywatnych, w mniejszym 
zaś stopniu dotyczą menedżerów organizacji państwowych. Inne badania wykazały, że u menedżerów bardzo silnie objawia się cecha dominacji i osiągnięć, z których ostatnia nie zawsze bywa efektywnie realizowana. Polski menedżer - według tych badań - jest mało kreatywny, preferuje standardowe, nawykowe rozwiązania, jedynie nieliczni zdobywają się na twórcze, nowatorskie, dość ryzykowne, ale właściwe decyzje. Ta preferencja sprawdzonych schematów działania może spowodować niezdolność do przewidywania następstw aktualnych sytuacji w przyszłości. Inne badania dowodzą, że menedżer ceni sobie pewność zatrudnienia, stabilizację pracy w organizacji, w której ma szansę na osiągnięcie sukcesu. Chce mieć wyraźnie określone zadania, zakres kompetencji i odpowiedzialności za ich realizację. Jego rola ogranicza się do określania zadań i kontroli ich wykonania. Kontakty z przełożonym nie mają dla niego większego znaczenia, a swoje zadania realizuje przy pomocy dobrego zespołu pracowników, w którym ma szeroką autonomię. Pragnie osiągnąć sukces, niemierzony jednak pozycją w strukturze organizacji czy poziomem dochodów, ale stopniem rzeczywistego współprzyczyniania się do sukcesu całej organizacji.

Nowoczesne zarządzanie organizacją wymaga menedżerów odważnych, zmierzających ku lepszej organizacji, wprowadzających zmiany, potrafiących szybko reagować na ich pojawienie się oraz wykorzystujących je do podejmowania nowych, ryzykownych działań (Stoner, Freeman, Gilbert 2001).

Obecnie w zarządzaniu szczególnego znaczenia nabiera chęć podejmowania ryzyka i ponoszenia za nie odpowiedzialności. Menedżer powinien wprowadzać zmiany, musi planować swoją przyszłość i przyszłość swojej organizacji długofalowo. Musi umieć przewidywać i oceniać przyszłe wydarzenia, stany rzeczy i ich skutki. Zarządzanie wymaga twórczej i inspirującej pomysłowości i przedsiębiorczości, energii i wyobraźni, a nade wszystko dbałości, aby wszyscy pracownicy zmierzali w pożądanym kierunku i realizowali założone cele i wynikające $\mathrm{z}$ nich zadania.

P.F. Drucker za najważniejszą cechę menedżera uważa efektywność. W jego rozumieniu efektywność jest wypadkową dwóch cech: sprawności (robienie rzeczy we właściwy sposób) i skuteczności (robienia właściwych rzeczy). Chociaż sprawność jest ważna, podstawowe znaczenie dla organizacji ma jednak skuteczność menedżera. Od menedżera wymaga się więc, aby jego działalność była jednocześnie skuteczna i sprawna. Skuteczność oznacza tutaj umiejętność wyboru właściwego celu (przedmiotu działania) i metod jego realizacji, m.in. koncentrowanie na nim w najkorzystniejszy sposób zasobów materialno-energetycznych i informacyjnych oraz wysiłku ludzkiego. Sprawni menedżerowie odznaczają się umiejętnością przyjmowania różnych postaw w zależności od okoliczności. P.F. Drucker (1994), oprócz efektywności, wyróżnia inne cechy składające się na osobowość menedżera:

- dobrą organizację czasu własnej pracy,

- osobistą aktywność,

- umiejętność współpracy z ludźmi (zarówno podwładnymi, jak i przełożonymi),

- komunikatywność,

- ciągłe samodoskonalenie,

- umiejętność podejmowania decyzji kierowniczych.

W jego rozumieniu efektywność pozostaje jednak w pewnym dystansie do wysokiej inteligencji, wyobraźni i wiedzy. Oznacza to, że samo posiadanie tych trzech atrybutów nie jest gwarancją skuteczności, choć na pewno stanowią one podstawowe składniki wzorca osobowości menedżera. Z podejściem P.F. Druckera zgadzają się J.A.F. Stoner i Ch. Wankel (2001). Do skuteczności odwołuje się również M. Armstrong (1997, 2006), twierdząc, że w celu wykształcenia tej cechy należy zrozumieć, co robią skuteczni, obserwować skutecznych, 
analizować własne zachowania oraz uczyć się wszystkiego, co jest dostępne na temat technik zarządzania.

$\mathrm{Na}$ wiele innych cech sprawnego menedżera wskazuje M. Armstrong, ujmując je jako zalecenia: znajomość podstawowych faktów, właściwa wiedza zawodowa, stała wrażliwość na to, co się dzieje, umiejętności analityczne, umiejętność rozwiązywania problemów, umiejętność podejmowania decyzji, umiejętność dokonywania oceny, zalety i umiejętności towarzyskie, odporność emocjonalna, wola działania, predyspozycje do twórczego myślenia (wyobraźnia), gibkość umysłowa, ustalone nawyki i umiejętności uczenia się, wiedza o samym sobie, gotowość do podejmowania ryzyka, umiejętność inspirowania entuzjazmu, twardość i stanowczość, asertywność, tzn. domaganie się respektowania swoich praw w taki sposób, aby nie naruszać praw innych osób, wyrażanie własnych potrzeb, chęci, opinii, odczuć i przekonań w bezpośredni i szczery sposób, myślenie lateralne, innowacyjność, logiczne, jasne myślenie, komunikatywność i dar przekonywania (Armstrong 2006, Bjerke 2004).

Oprócz wyżej wymienionych cech (rekomendacji), menedżer powinien wykazywać zmysł praktyczny oraz dużą elastyczność w pracy kierowniczej. Zmienne warunki jej prowadzenia wymagają dużej energii, wytrwałości w działaniu oraz aktywności. Bierność i poddawanie się okolicznościom oceniane są negatywnie. Menedżer powinien mieć zmysł spostrzegawczy i umiejętność obserwowania faktów, obiektywnego badania przyczyn i wyciągania wniosków.

Z uwagi na tak liczne cechy osobowe wymieniane przy identyfikacji wzorów osobowościowych menedżerów przez różnych autorów, często podejmowane są próby ustalenia najważniejszych cech, jakimi powinien odznaczać się menedżer. Sądzę, że za dodatnie cechy osobowe tworzące osobowość menedżera zbliżoną do idealnej można, z pewnym uproszczeniem, uznać:

- twórczą wyobraźnię i inwencję, szeroki horyzont myślowy,

- umiejętność przewidywania przyszłych zdarzeń, stanów rzeczy i ich skutków,

- zdolności przywódcze,

- odwagę, zdecydowanie i zdolność podejmowania decyzji, nawet ryzykownych, stosownie do okoliczności,

- nieprzeciętną energię, silną wolę i stałość charakteru,

- komunikatywność oraz umiejętności wzbudzania zaufania i przekonywania,

- umiejętność pracy w zespole i współdziałanie z nim, poczucie więzi grupowej oraz poświęcenie dla organizacji,

- inteligencję, przejawiającą się w wyborze właściwego postępowania w nieprzewidzianych sytuacjach,

- elastyczność w działaniu, takt i życzliwość,

- inicjatywę i przedsiębiorczość, przejawiającą się w poszukiwaniu nowych rozwiązań i podejmowaniu nowych przedsięwzięć,

- poczucie osobistej odpowiedzialności,

- uczciwość, sprawiedliwość i poszanowanie prawa,

- stałe podnoszenie umiejętności kierowniczych i poszerzanie wiedzy ogólnej,

- zdolność jasnego i zwięzłego wyrażania myśli.

Niezbędne są też profesjonalizm (kwalifikacje zawodowe, kompetencje menedżerskie) i wysoki poziom etyczno-moralny. Uważa się, że umiejętność postępowania z ludźmi i podnoszenie efektywności pracy zespołowej to $85 \%$ sukcesu w pracy zawodowej menedżera.

Jakkolwiek w procesie zarządzania cechy osobowościowe menedżera są bardzo istotne, to jednak w jego kształceniu i doskonaleniu nie można koncentrować się wyłącznie na osobowości, jej wzbogacaniu i rozwijaniu. Cechy osobowościowe, wiedza, umiejętności i doświadczenie oraz sprawność intelektualna decydują o postępowaniu menedżera z ludźmi i jego określonych 
oddziaływaniach, reakcjach. Jednak w rzeczywistości sukces menedżera zależy w dużej mierze od tego, w jakim stopniu potrafi on pogodzić swoje wrodzone i wykształcone cechy osobowościowe z oczekiwaniami przełożonych i podwładnych.

Jaki powinien być wymiar osobowości idealnego menedżera? Wydaje się, że jednoznacznej odpowiedzi jeszcze nie ma. Dotychczasowe liczne badania i doświadczenia nie pozwoliły jeszcze ustalić właściwego zestawu elementów profesjonalnych i cech osobowości czy szerzej - wzorca idealnego menedżera, odnoszącego prawdziwe sukcesy w działalności kierowniczej. Teoria cech kierowniczych jest zawodna i jak dotąd nie została potwierdzona empirycznie. Długie listy różnorodnych cech osobowości i elementów zaliczanych do wymiaru profesjonalnego menedżera nie wystarczają do nakreślenia sylwetki skutecznego, sprawnego i efektywnego kierownika. Niezbędne są dalsze badania w tym zakresie z uwzględnieniem (wskazaniem) wartości (zasad) etyczno-moralnych.

\section{Podsumowanie}

Sylwetka menedżera była, jest i na pewno będzie w przyszłości tematem wielu różnorodnych badań, poszerzonych analiz i publikacji. Na ich podstawie będzie można określić zespół cech tworzących charakterystykę współczesnego menedżera. Ważne jest, w jaki sposób menedżer podejmuje decyzje, jaka jest ich jakość i jaki jest stosunek menedżera do pracowników. Są to działania wymagające poważnej wiedzy i dużych umiejętności, w tym kierowniczych, których można się nauczyć. Ponadto od sprawnego menedżera, oprócz kwalifikacji - kompetencji zawodowych, wymaga się silnej osobowości, wyobraźni, odwagi, zdolności kierowniczych i inteligencji, pozwalających na myślenie perspektywiczne i nowatorskie działania, wysokiego poziomu kultury osobistej oraz kierowania się w pracy zarządczej uznawanymi wartościami etyczno-moralnymi, związanymi z regułami ułatwiającymi dokonywanie wyborów ochraniających jednostkę ludzką i jej godność przed krzywdą i niesprawiedliwością, wskazujących jednocześnie źródła i sposoby unikania niebezpieczeństw, prezentującymi uniwersalne i niezbywalne wartości ludzkie służące człowiekowi, solidarności i dobru wspólnemu.

W szerszym kontekście należy zaznaczyć, że w sprawnym i efektywnym rozwiązywaniu przez menedżerów powstających problemów zarządczych w warunkach globalizacji, rozumianej jako proces zagęszczania i intensyfikacji wzajemnych powiązań, w tym przestrzennych między różnymi podmiotami w skali krajowej i światowej, konieczne jest współdziałanie nie tylko sfer ekonomicznej, finansowej, społecznej, ekologicznej i politycznej, ale także sfery etyczno-moralnej, by nie dopuścić do globalnego upadku, katastrofy systemu ekonomicznego, czego symptomem jest już realna groźba upadku systemu bankowego (finansowego).

\section{Literatura}

1. Armstrong M., 1997, Jak być lepszym menedżerem, Dom Wydawniczy ABC, Warszawa.

2. Armstrong M., 2006, Zarzadzanie zasobami ludzkimi, Oficyna Ekonomiczna, Warszawa.

3. Banaszek S., 2006, Menedżerowie w strukturze społecznej, WSKiZ, Poznań.

4. Bartkowiak G., Januszek H., 1999, Umiejętności kierownicze, AE, Poznań.

5. Bjerke B., 2004, Kultura a style przywództwa, Oficyna Ekonomiczna, Kraków.

6. Brzeziński P., 1999, Koncepcja TQM - historia i rozwój idei, „Problemy Jakości”, 5/1999.

7. Coates Ch., 1998, Menedżer wszechstronny, Wyd. BSP, Warszawa.

8. Drucker P.F., 1994, Menedżer skuteczny, AE, Kraków.

9. Kietliński K., Martinez-Reyes V., Aleksyn T., 2004, Etyka w biznesie i zarządzaniu, Oficyna Ekonomiczna, Kraków.

10. Koźmiński A., Piotrowski W. (red.), 2006, Zarządzanie. Teoria i praktyka, PWN, Warszawa. 
11. Krzyżanowski L.J., 1999, O podstawach zarządzania inaczej: paradygmaty, modele, metafory, filozofia, metodologia, dylematy, trendy, PWN, Warszawa.

12. Kubik K., 2005, Menedżer w przedsiębiorstwie przyszłości, Dom Organizatora TNOiK, Torun.

13. Kubik K., 2008, Kultura menedżerska, WWSE, Warszawa.

14. Kuc B. R., 2004, Od zarządzania do przywództwa, Wyd. Menedżerskie PTM, Warszawa.

15. Penc J., 2001, Wizerunek menedżera przyszłości, „Ekonomika i Organizacja Przedsiębiorstwa”, $8 / 2001$.

16. Probst G., Raub S., Romhardt K., 2004, Zarzadzanie wiedza w organizacji, Oficyna Ekonomiczna, Warszawa.

17. Psychologiczne czynniki sukcesu w zarzadzaniu, S. Witkowski (red.), 1996, Wyd. Uniwersytetu Wrocławskiego, Wrocław.

18. Rachwał M.M., Rachwał T., 2006, Wartości moralne podstawa prawdziwego sukcesu menedżera [w:] Rola przedsiębiorczości w podnoszeniu konkurencyjności społeczeństwa i gospodarki, Z. Zioło, T. Rachwał (red.), Przedsiębiorczość-Edukacja nr 2, Zakład Przedsiębiorczości i Gospodarki Przestrzennej IG AP w Krakowie, Wydawnictwo Nowa Era, Warszawa-Kraków.

19. Rakowska A., Sitko-Lutek A., 2000, Doskonalenie kompetencji menedżerskich, PWN, Warszawa.

20. Schein E.H., 1997, Przywództwo a kultura organizacji [w:] Lider przyszłości. Nowe wizje, strategie i metody dziatania na nadchodzaca erę, F. Hesselbein, M. Goldsmith, R Beckhard (red.), Business Press, Warszawa.

21. Stoner J., Freeman R., Gilbert D., 2001, Kierowanie, PWE, Warszawa.

22. Stoner J., Wankel Ch., 2001, Kierowanie, PWE, Warszawa.

23. Surna P., 1998, Kultura zawodu dla ekonomistów, Wyd. eMPi2, Poznań.

24. Szczupaczyński J., 1998, Anatomia zarządzania organizacją, Międzynarodowa Szkoła Menedżerów, Warszawa.

25. Wachowiak P., 2001, Profesjonalny menedżer, Difin, Warszawa.

26. Wołowiec T., 2009, CSR - a Marketing Strategy or Responsible Business? (Selected Issuses), Hochschule, Hof.

27. Zarzadzanie kompetencjami w organizacji, E. Małyk-Musiał (red.), 2005, Wyd. GRAF, Warszawa.

28. Zawiślak A., 2003, Cechy i umiejętności menedżera wobec wyzwań globalizacji [w:] Menedżer XXI wieku, E. Bajor (red.), PL- TNOiK, Lublin.

29. Żukowski P., 1989, Kierowanie przedsiębiorstwem przemysłowym w przy produkcji seryjnej, PWN, Warszawa - Wrocław.

30. Żukowski P., 2005, Wymiar osobowy i etyczny współczesnego menedżera [w:] Współczesne problemy edukacji, pracy i zatrudnienia pracowników, B. Pietrulewicz (red.), UZ, Zielona Góra.

31. Żukowski P., 2006, Podstawy nauk o zarzadzaniu, Oficyna Wydawnicza Politechniki Rzeszowskiej, Rzeszów.

32. Żukowski P., 2008, Podstawy naukowej organizacji pracy z wybranymi problemami zarzadzania, WSZiA, Opole.

\section{Profesional and Personal Aspect of Modern Manager}

The paper introduces two aspects of the suggested profile of modern manager: in relation to his/her profession and personality. Roles, functions and tasks of manager as well as the elements of his professional model and key management abilities (personal and interpersonal), typologies of managers and set of personal characteristics the manager needs in organization, were presented. 